\title{
Training Cost and Financial Performance Nexus: Sector Analysis of Quoted Manufacturing Firms in Nigeria
}

\author{
Oluka Nyime OBULOR ${ }^{1} \quad$ John OHAKA, $\mathrm{PhD}^{2 *}$ \\ 1. Department of Accountancy, Ignatius Ajuru University of Education Rumuolumeni, Rivers State - Nigeria \\ 2. Department of Accountancy, Rivers State University Port Harcourt, Rivers State - Nigeria
}

\begin{abstract}
Accounting functionaries are increasingly recognizing that human capital features productive capabilities, which manifest as skills, experience, and knowledge. These valued competencies make personnel adaptable, productive and competitive amongst contemporaries. This study, therefore, focuses on quoted manufacturing firms in Nigeria to determine the effect of human resource cost on financial performance. Adopting ex-post facto design, with panel data spanning 2008 to 2017, the operationalized variables are training cost, return on equity, and earnings per share. Financial time series of all 20 quoted manufacturing firms in Nigeria were obtained for analysis, as contained in Nigerian Stock Exchange publications. Data analysis details and results are presented in terms of Correlation Coefficient (R), Coefficient of Determination $\left(\mathrm{R}^{2}\right)$, T-test, F-test, and Granger Causality. Following the outcome ( 1.660 critical t-value at $0.05<3.734$ computed $t$-value), the first null hypothesis is rejected, in favour of the alternate hypothesis, which states that training cost has significant effect on return on equity. Also, regarding the second hypothesis, the adjusted $\mathrm{R}^{2}$ of 0.594 implies that training cost explains $59.4 \%$ of the variations in earnings per share. These revelations affirm that human resource cost has significant effect on financial performance of quoted manufacturing firms in Nigeria. It is, therefore, recommended that the firms should recognize human capital investment as prime requisite for corporate performance, and strive to improve their human capital investment to total assets ratio. They also consistently ensure proper classification of cost under their capital and revenue expenditure sub-heads to standardize their financial reporting system.
\end{abstract}

Keywords: Financial performance, training cost, manufacturing firms.

DOI: $10.7176 /$ RJFA/10-18-10

Publication date:September $30^{\text {th }} 2019$

\section{Introduction}

One of the biggest challenges accounting professionals have to grapple with has to do with assigning monetary values to, and capitalizing different dimensions of human resource cost, investment, and worth of employees. A number of modes to facilitate the process had been projected over the years, including the Adjusted (Present) Value Method (Hermanson, 1964), Goodwill Method (Brummet, Flamholtz \& Pyle, 1969), Discounted Wages Method (Lev \& Schwartz, 1971), and Historical Acquisition Cost Method (Flamholtz, 1971). The Replacement Cost Method is also considered in contemporary analysis (Micah, Ofurum \& Ihendinihu, 2015; Oluka, 2019). While the above methods have been operational in developed countries, they are not much applied in developing countries, including Nigeria. This is the scenario in which this study examines the effect of human resource cost on financial performance of quoted manufacturing firms in Nigeria. The objectives of the study include to:

i. Ascertain the effect of training cost on the return on equity of quoted manufacturing firms in Nigeria; and

ii. Assess the effect of training cost on the earnings per share of quoted manufacturing firms in Nigeria.

The following hypotheses are formulated towards achieving the objectives:

$\mathrm{Ho}_{1}$ : $\quad$ Training cost has no significant effect on the return on equity of quoted manufacturing firms in Nigeria.

$\mathrm{Ho}_{2}$ : Training cost has no significant effect on the earnings per share of quoted manufacturing firms in Nigeria.

\section{Literature Review}

Cost arises from a sacrifice incurred to obtain some anticipated benefit or service. It consists of expense element and asset element. The expense element provides benefits during the current accounting period, while the asset element is expected to give rise to benefits in the future. This study is identified with the cost-based model of human resource expenditure measurement. Other measurements adopted by accounting professionals are based on the historical cost model, replacement cost model, opportunity cost model, standard cost model, and economic value model (Newman, 1999; Cascio, 1998).

The historical cost of human resources is the sacrifice made in getting personnel. It seeks to recognize the actual cost incurred in recruiting selecting, hiring, training and development of employee, which are capitalized and amortized over the expected useful life of the human resource. The replacement cost of human resource is the amount that would be incurred if the present employees are to be replaced. It estimates the current market value, as human resource is valued on the assumption that a new similar organization will be created from the scratch. 
By this, cost to the firm is calculated if the existing human resources are to be replaced with other persons of equivalent talents, skill and experience. The costs incurred by an organization in replacing terminated employees, for instance, relate to advertisement, reemployments administrative function, interviews, and traveling cost, amongst others. However, this approach is weak due to the inability of firms to replace knowledge, competency, and loyalty of human resource precisely.

The opportunity cost model, also known as market value method, is based on the economic concept of opportunity cost. It relates to the value of an asset when there is an alternative opportunity of using it. This implies that there is no opportunity cost for human resources who are not scarce (hence only scarce people form part of the human resource cost outlay). An employee is scarce when the employment of such person denies competitors the possessed talent, skill and experience. Thus, opportunity cost relates to the offer made by other employers to attract the employee. The goodwill model is used for valuation, when a firm makes return on investment above the industry average, hence the capitalization infer that unstated human resource value are presented within the organization to account for the excess earnings.

Hermanson (1964) posited that supernormal earning is indicative of resources not shown on the balance sheet. Determining this involves forecasting future earnings and allocating any excess above normal expected earnings to human resources. The weakness, however, remains that it underestimates the value of human resources, limiting it to the amount in excess of normal earnings (and ignoring the actual human resource base required to carry out normal operation). It also uses earnings of the most recent years as basis, thereby ignoring forecast of future earnings which is equally useful in managerial decisions. The economic value model advocates that group value should be determined by estimating contributions to the total economic value of the firm. By this, a firm forecasts future earnings and subsequently discounts them to reflect the present value, so that a portion is allocated to human resources according to their contributions. The weakness of this model stems from the challenge of contribution quantification.

To make the accounting for human resource cost more meaningful and justify its inclusion in statement of financial position as asset, it is important to classify the cost incurred into capital expenditure and revenue expenditure (Cascio, 1998). The capital expenditure should be capitalized and recorded in the balance sheet as intangible assets and amortized over the useful life of the human asset. The amortized value is to be recorded as expenses in the statement of firm position while the revenue expenditure is charge to revenue in the statement of comprehensive income. This becomes the human resource cost featured in the financial statements. The capital expenditure may also be treated as investment in human resource asset under intangible assets, although intangible assets have no general accepted definition. They are usually accompanied with different concepts relating to investment assets, amongst others (Canibano, García-Ayuso, Sánchez, \& Olea, 1999).

Furthermore, Woodruff Jr. (1970) and Mirvis and Macy (1976) contend that this treatment is justified since development costs provide benefits beyond the current accounting period. Moreover, investors and management need information on human assets to steer organizations to higher financial performance. The Return on Equity (ROE) assesses only the benefits of equity owners, whereas the ROA aggregates the return of equity-holders and debt-holders. Earnings per share (EPS) as a ratio, assesses earnings in relation to every share issued by a firm. It reveals how much a share of the firm earns from the annual earnings (Okpala \& Chidi, 2010; Oluka, 2019). The independent variable in this study is training cost. This encompasses cost incurred in relation to human resource induction/training cost, which relates to training of selected recruits prior to their job placement and actual start of work; as well as cost incurred on human resource education, training and development cost, which is directed at updating the knowledge of human resource in order to make them more competitive and productive. The various manifest of training cost are capitalized and added to the total value of human resources in the organization.

According to Becker (1964), under the human capital theory, people constitute an organization's human capital, which like every other asset owned by a firm would have a value in the market place under conditions of stable employment. However, unlike other assets, the potential value of human capital can only be fully realized with the co-operation of the person. Experts admit that human capital is the collective value of the capabilities, knowledge, skills, life experiences, and motivation of the workforce in an organization. Thus, all costs related to expected productive behaviour in the form of incentives to motivate, monitor and retain them should constitute human capital investments made in anticipation of future output (Flamholtz, 1999). Wright and McMahan (1992), making a case for resource-based theory, contended that human resources provide a source of sustained competitive advantage, provided they:

i. They add value to the firm's production processes;

ii. $\quad$ The skills that the firm seeks are rare; and

iii. The combined human capital investments a firm's employees represent are not easily imitated.

The resource base theory of human resource management, thus, looks at human capital like every other valued asset of the firm. It views human resource as investment rather than amount to be expensed (Beardwell \& Holden, 2003). By this, Eatwell and Newman (1991) define productivity as ratio of a measure of output to an index of input. This projects productivity as the arithmetic ratio of the amount produced to the amount of resources used in 
the course of production. Samuelson and Nordhaus (1995) observed that this concept of productivity is indicative of the output per unit or efficiency with which resources are utilized. Thus, productivity relates to attainment of the highest level of performance with the lowest possible expenditure of resources, representing the ratio of the quality and quantity of products to the resources utilized. Contextual factors also partly determine availability of the types and amounts of skills and knowledge a firm needs from the external labour market.

Some empirical studies have been conducted to ascertain the relationship between human resource cost and financial performance, leading to different claims and objections. The effect of human resource cost on financial performance in selected listed firms in Nigeria has also attracted much research interest in recent times. In a related study, secondary data on relevant financial variables were extracted from published financial statements of selected listed firms in Nigeria, while Ordinary Least Square (OLS) regression method was adopted using the Statistical Package for Social Sciences (SPSS). The results revealed that personnel benefit costs have positive and significant effect on profitability, leading to the conclusion that investments in human resources have positive effect on profitability (Micah, Ofurum \& Ihendinihu, 2015). It was recommended that there should be greater financial commitment to manpower training and development, while providing proper infrastructure and more conducive working environment to enhance the productive capacity of employees and drive improvement in corporate financial performance.

Adebawojo, Enyi and Adebawo (2018) examined the effect of human resource costs on financial performance of quoted companies in Nigeria, using pay data in OLS regression analysis. The study revealed that human resource costs have positive effect on financial performance of quoted companies in Nigeria. Their conclusions are in line with those of Okpala and Chidi (2010), hence the recommendation that accounting standard setting bodies should do more to promote accounting practices which relate to human resource cost and financial performance. Abubakar (2008) examined the necessity of human resource accounting and the need for an alternative procedure in determining human resource value. The findings from these studies were quite useful in arriving at a realistic human resource valuation model, in line with the stakeholders' expectations.

Ekwe (2012) examined the relationship between intellectual capital and financial performance in the Nigerian banking sector, using multiple regression analysis method. With the aid of SPSS in data analysis, the study revealed that there is positive and significant relationship between components of the Value Added Intellectual Coefficient (VAIC) and Return on Assets, components of VAIC and human resource productivity, and components of VAIC and market to book value ratio of the banks. The present study focuses on the Nigerian manufacturing sector, with the intent of determining the effect of human resource cost on financial performance.

\section{Method}

This study adopts ex-post facto research design as the framework upon which effect of human resource cost on financial performance of manufacturing firms in Nigeria is examined. The specified time frame is 2008 to 2017 , while the entire population of 20 quoted manufacturing firms quoted on the Nigerian Stock Exchange (NSE) is involved, thus, aggregating to form the panel data required for the purpose of analysis (Davies, 2018). The firms are identified as follows:

$\begin{array}{ll}\text { i. } & \text { Champion breweries, } \\ \text { ii. } & \text { Seven Up Bottling Co, } \\ \text { iii. } & \text { Ashaka cement, } \\ \text { iv. } & \text { Cadbury, } \\ \text { v. } & \text { UAC, } \\ \text { vi. } & \text { Evans Medical, } \\ \text { vii. } & \text { Pabod Breweries, } \\ \text { viii. } & \text { Flour Mills, } \\ \text { ix. } & \text { Guinness, } \\ \text { x. } & \text { Glaxo, } \\ \text { xi. } & \text { Lafarage, } \\ \text { xii. } & \text { May and Baker, } \\ \text { xiii. } & \text { Nestle, } \\ \text { xiv. } & \text { Nigeria Bag, } \\ \text { xv. } & \text { Nigeria Ropes, } \\ \text { xvi. } & \text { Nigeria Breweries, } \\ \text { xvii. } & \text { PZ Cussons, } \\ \text { xviii. } & \text { Unilever, } \\ \text { xix. } & \text { University Press, and } \\ \text { xx. } & \text { Vita Foam. }\end{array}$

Secondary (time series) data on the firms are drawn from NSE publications of the specified years, with particular reference to the statements of financial position and income. The dependent variable is financial 
performance, with ROE and EPS as proxies; while the independent variable is human resource cost, with Training Cost (TC) as proxy. The model specification is as follows:

$Y=\beta_{0}+\beta_{1} X i t+u$

Where:

$\begin{array}{lll}Y & = & \text { Dependent Variable } \\ \beta_{0} & = & \text { Regression Intercept } \\ \beta_{1} \text { Xit } & = & \text { Independent variable } \\ u & = & \text { Error Term }\end{array}$

To justify the multiple regression approach, the elements in Equation (1) are complemented with two additional relevant independent variables, namely wage and salary cost and pension cost (Osuala, 2001; Oloyo, 2001; Oluka, 2019). The specific functions concentrating on the hypotheses are as follows:

Hypothesis I: $R O E=\beta 0+\beta 1 T C+u$

Hypothesis II: $E P S=\beta_{0}+\beta_{2} T C+u$

The main quantitative dimensions of statistical analysis include:
i. $\quad$ Correlation coefficient (R),
ii. Coefficient of determination $\left(\mathrm{R}^{2}\right)$,
iii. T-value,
iv. F-value, and
v. Granger Causality value.

The level of significance, for inferential purposes, is stipulated as 0.05 (which indicates $95 \%$ confidence). ROE and EPS, the dependent variables and proxies of financial performance, derived as follows:

$\mathrm{ROE}=[$ Profit before Interest \& Tax $] /[$ Shareholders' Funds $]$

$\mathrm{EPS}=[$ Profit before Interest \& Tax]/[No. of Outstanding Shares ]

\section{Results}

To ensure uniformity of magnitudes, the dependent variables are quantified relative as percentage of total cost. The statistical dimensions of data analysis are presented in relation to correlation, regression, and Granger causality. The Granger causality test ascertains the causal relationship running from independent variable to dependent variable and from dependent variable to independent variable. The details in terms of model appropriateness, Tvalue and F-value under Fixed Effects (FE) and Random Effects (RE) models, Granger causality test, Error Correction Model (ECM, and test of hypotheses, are presented in Tables 1 to 7:

Table 1: Model Appropriateness Test Results

\begin{tabular}{|c|c|c|c|}
\hline \multirow{2}{*}{\multicolumn{4}{|c|}{ Human Resource Cost and Return on Equity of Quoted Manufacturing Firms in Nigeria }} \\
\hline & & & \\
\hline Effects Test & Statistic & d.f. & Prob. \\
\hline Cross-section F & 0.533949 & $(19,177)$ & 0.9443 \\
\hline Cross-section Chi-square & 11.146838 & 19 & 0.9188 \\
\hline \multicolumn{4}{|c|}{ Correlated Random Effects - Hausman Test } \\
\hline Test Summary & Chi-Sq. Statistic & Chi-Sq. d.f. & Prob. \\
\hline Cross-section random & 4.896124 & 3 & 0.0000 \\
\hline \multicolumn{4}{|c|}{$\begin{array}{l}\text { Human Resource Cost and Earnings per Share of Quoted Manufacturing Firms in Nigeria } \\
\text { Redundant Fixed Effects Tests }\end{array}$} \\
\hline Effects Test & Statistic & d.f. & Prob. \\
\hline Cross-section F & 0.876050 & $(19,175)$ & 0.6129 \\
\hline Cross-section Chi-square & 17.989967 & 19 & 0.5231 \\
\hline \multicolumn{4}{|c|}{ Correlated Random Effects - Hausman Test } \\
\hline Test Summary & Chi-Sq. Statistic & Chi-Sq. d.f. & Prob. \\
\hline Cross-section random & 2.424949 & 3 & 0.0090 \\
\hline
\end{tabular}

Source: E-view Output 9.0 (2019)

The results in Table 1 indicate that the $p$-value is significant $(p=0.0000)$, and this goes in favour of the FE model. This outcome prevails with both the ROE cross-section random result $(\mathrm{p}=0.0000$ at the 0.05 level) and the EPS cross-section random ( $\mathrm{p}=0.0091$ at the 0.05 level). 
Table 2: Fixed Effect Results

\begin{tabular}{|c|c|c|c|c|}
\hline Variable & Coefficient & Std. Error & t-Statistic & Prob. \\
\hline \multicolumn{5}{|c|}{ Human Resource Cost and Return on Equity of Quoted Manufacturing Firms in Nigeria } \\
\hline TC & -0.110949 & 0.029712 & -3.734091 & 0.0003 \\
\hline \multirow[t]{2}{*}{$\mathrm{C}$} & -2.624676 & 2.100649 & -1.249460 & 0.2131 \\
\hline & Effects Spe & ication & & \\
\hline \multicolumn{5}{|c|}{ Cross-section fixed (dummy variables) } \\
\hline R-squared & 0.621005 & Mean dependent var & & 14.45285 \\
\hline Adjusted R-squared & 0.436611 & S.D. dependent var & & 2.386954 \\
\hline S.E. of regression & 2.085533 & Akaike info criterion & & 4.415758 \\
\hline Sum squared resid & 769.8520 & Schwarz criterion & & 4.795065 \\
\hline Log likelihood & -418.5758 & Hannan-Quinn criter. & & 4.569258 \\
\hline F-statistic & 3.803617 & Durbin-Watson stat & & 1.839109 \\
\hline Prob(F-statistic) & 0.000000 & & & \\
\hline \multicolumn{5}{|c|}{ Human Resource Cost and Earnings per Share of Quoted Manufacturing Firms in Nigeria } \\
\hline Variable & Coefficient & Std. Error & t-Statistic & Prob. \\
\hline $\mathrm{TC}$ & -0.524108 & 1.185262 & -0.442187 & 0.6589 \\
\hline \multirow[t]{2}{*}{$\mathrm{C}$} & 20.58898 & 91.13116 & 0.225927 & 0.8215 \\
\hline & Effects Spe & ication & & \\
\hline \multicolumn{5}{|c|}{ Cross-section fixed (dummy variables) } \\
\hline R-squared & 0.594510 & Mean dependent var & & 17.65162 \\
\hline Adjusted R-squared & 0.319323 & S.D. dependent var & & 87.06020 \\
\hline S.E. of regression & 87.89732 & Akaike info criterion & & 11.89906 \\
\hline Sum squared resid & 1352039. & Schwarz criterion & & 12.28103 \\
\hline Log likelihood & -1155.007 & Hannan-Quinn criter. & & 12.05367 \\
\hline F-statistic & 4.830248 & Durbin-Watson stat & & 2.255461 \\
\hline Prob(F-statistic) & 0.000091 & & & \\
\hline
\end{tabular}

Source: E-view Output 9.0 (2019)

The results in Table 2 indicate that the independent variable can explain $62 \%$ of the variations in the dependent variable. The F-statistic and probability value indicate that the model is significant in determining changes in the dependent variable. The t-statistic and probability value also indicate that the independent variable is significant in explaining variations in the dependent variable, and prevalent with both the $\mathrm{ROE}(\mathrm{P}=0.0000$ at the 0.05 level $)$ and the EPS $(\mathrm{P}=0.000091$ at the 0.05 level $)$.

Table 3: Causality Test Results

\begin{tabular}{lccr}
\hline Null Hypothesis: & Obs & F-Statistic & Prob. \\
\hline \multicolumn{4}{r}{ Human Resource Cost and Return on Equity of Quoted Manufacturing Firms in Nigeria } \\
TC does not Granger Cause ROE & 160 & 23.0325 & 0.0000 \\
ROE does not Granger Cause TC & & 50.3874 & 0.0000 \\
& & \\
Human Resource Cost and Earnings per Share of Quoted Manufacturing Firms in Nigeria \\
Null Hypothesis: & Obs & F-Statistic & Prob. \\
TC does not Granger Cause EPS & 156 & 0.11962 & 0.8873 \\
EPS does not Granger Cause TC & & 0.60409 & 0.5479
\end{tabular}

\section{Source: E-view Output 9.0 (2019)}

The results in Table 3 indicate that the independent variable Granger cause the dependent variable, and this is more prevalent with the $\operatorname{ROE}(\mathrm{P}=0.0000$ at the 0.05 level $)$. 
Table 4: Co-integration Test Results

Pedroni Residual Cointegration Test

\begin{tabular}{|c|c|c|c|c|}
\hline \multicolumn{5}{|c|}{ Human Resource Cost and Return on Equity of Quoted Manufacturing Firms in Nigeria } \\
\hline \multicolumn{5}{|c|}{ Series: ROE TC } \\
\hline \multicolumn{5}{|c|}{ Alternative hypothesis: common AR coefs. (within-dimension) } \\
\hline & $\underline{\text { Statistic }}$ & Prob. & $\begin{array}{c}\text { Weighted } \\
\text { Statistic }\end{array}$ & Prob. \\
\hline Panel v-Statistic & 0.206588 & 0.4182 & -1.866223 & 0.9690 \\
\hline Panel rho-Statistic & 1.881618 & 0.9701 & 2.410314 & 0.9920 \\
\hline Panel PP-Statistic & -5.474887 & 0.0000 & -3.578572 & 0.0002 \\
\hline Panel ADF-Statistic & -1.501057 & 0.0667 & -2.280285 & 0.0113 \\
\hline \multicolumn{5}{|c|}{ Alternative hypothesis: individual AR coefs. (between-dimension) } \\
\hline & $\underline{\text { Statistic }}$ & Prob. & & \\
\hline Group rho-Statistic & $\overline{4.208160}$ & $\overline{1.0000}$ & & \\
\hline Group PP-Statistic & -8.163257 & 0.0000 & & \\
\hline Group ADF-Statistic & -0.481512 & 0.3151 & & \\
\hline Pedroni Residual Coir & & & & \\
\hline
\end{tabular}

Human Resource Cost and Return on Equity of Quoted Manufacturing Firms in Nigeria

Series: EPS TC

Alternative hypothesis: common AR coefs. (within-dimension)

\begin{tabular}{|c|c|c|c|c|}
\hline & $\underline{\text { Statistic }}$ & Prob. & $\begin{array}{l}\text { Weighted } \\
\text { Statistic }\end{array}$ & Prob. \\
\hline Panel v-Statistic & -2.064420 & $\overline{0.9805}$ & -2.996139 & 0.9986 \\
\hline Panel rho-Statistic & 0.821070 & 0.7942 & 1.238077 & 0.8922 \\
\hline Panel PP-Statistic & -3.289389 & 0.0005 & -4.410192 & 0.0000 \\
\hline Panel ADF-Statistic & -0.132077 & 0.4475 & 2.424573 & 0.9923 \\
\hline \multicolumn{5}{|c|}{ Alternative hypothesis: individual AR coefs. (between-dimension) } \\
\hline & $\underline{\text { Statistic }}$ & Prob. & & \\
\hline Group rho-Statistic & 3.520477 & 0.9998 & & \\
\hline Group PP-Statistic & -7.684507 & 0.0000 & & \\
\hline Group ADF-Statistic & 1.216476 & 0.8881 & & \\
\hline
\end{tabular}

Source: E-view Output 9.0 (2019)

The results in Table 4 indicate that the variables are co-integrated, since the probability values are less than 0.05 . This goes in favour of the alternate hypotheses that there is the presence of long-run relationship between the dependent and the independent variables. 
Table 5: Estimated Error Correction Results

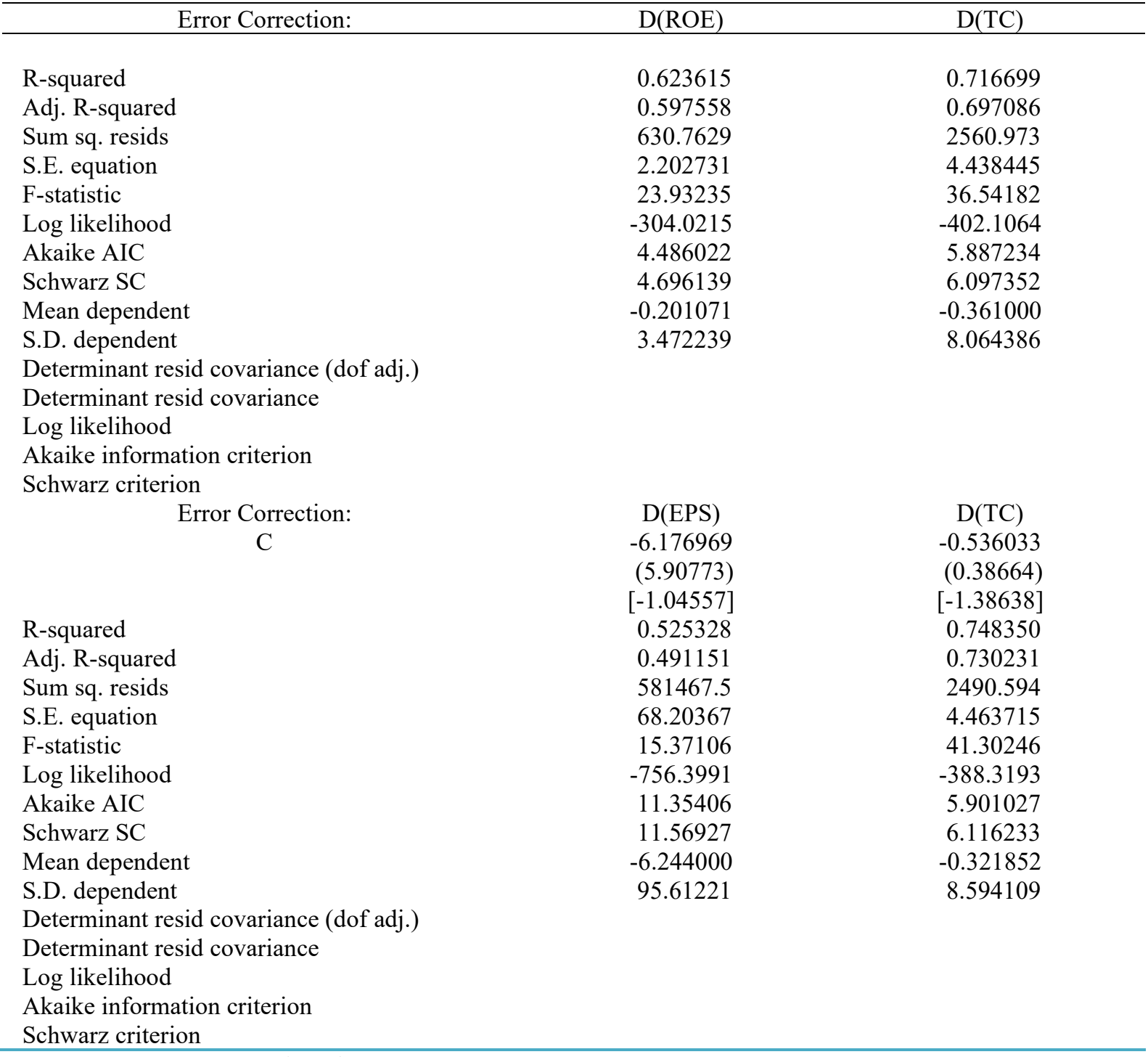

Source: E-view Output 9.0 (2019)

The results in Table 5 regarding the error correction model indicate that $71.6 \%$ of variations in the dependent variable can be explained by the independent variable.

\section{Table 6: Test Results of Hypothesis I}

\begin{tabular}{lll}
\hline & $R^{2}$ & .621 \\
Adjusted & $R^{2}$ & .436 \\
$T$ calculated & & 3.734 \\
T table & 1.660 \\
Significant level & $5 \%=0.025$ (two tail) \\
D.W & 1.839 \\
No of observation & 160 \\
\hline
\end{tabular}

Source: E-view 9.0

The results in Table 6 indicate that the critical t-value of \pm 1.660 is less than the computed t-value of 3.734. The Null Hypothesis I is, therefore, rejected. This favours acceptance of the Alternate Hypothesis I, which states that TC has significant effect on ROE of quoted manufacturing firms in Nigeria. 


\begin{tabular}{lcl} 
Table 7: Test Results of Hypothesis II & \\
\hline & $R^{2}$ & .594 \\
Adjusted & $R^{2}$ & .319 \\
T calculated & & 0.6589 \\
T table & 1.660 \\
Significant level & $5 \%=0.025$ (two tail) \\
D.W & 2.255 \\
No of observation & 160
\end{tabular}

Source: E-view 9.0

The results in Table 7 indicate an adjusted $\mathrm{R}^{2}$ of 0.594 , which implies that the independent variable can explain $59.4 \%$ of the variations in the dependent variable.

\section{Discussion of Findings}

The findings emanating from the above statistical results affirm that training cost (proxy for human resource cost) is significant in explaining variations in the return on equity and earnings per share (proxies for financial performance). Specifically, it is established that:

i. $\quad$ Training cost significantly Granger cause return on equity; and

ii. There is the presence of long run relationship between the training cost and Granger cause return on equity as well as earnings per share.

These findings favour acceptance of the alternate composite position that human resource cost has significant effect on the financial performance of quoted manufacturing firms in Nigeria. This stance is in line with the revelations obtained from many previous studies in the area of human resource accounting. In a related study which focused on human resource cost and financial performance of quoted companies in Nigeria, a causal comparative research design was adopted, with data from secondary sources. Correlation and multiple regression methods were adopted, which revealed that there is a significant relationship between remuneration and revenue growth. The study concluded that there is a positive and significant relationship between human resource cost and financial performance of quoted companies in Nigeria. In line with this conclusion, organizations were urged to consider establishment and development costs of human resources as strategic investment options necessary for providing corporate competitive edge (Okpala \& Chid, 2010; Micah, Ofurum \& Ihendinihu, 2015).

Kharal, Zai-ur-Rehman, Abrar \& Khan (2014) had also examined the effects of intellectual capital on the performance of companies in the oil and gas sector of Pakistan, using correlational research design and VAIC model. Data on the three components of VAIC (human capital, structural capital, and capital employed efficiency) alongside three measures of financial performance (return on assets, return on equity, and earnings per share) were extracted from 12 listed oil and gas companies over the period 2005-2013 (given an average of six years data for each company). Pooled OLS technique and correlation analysis were used in estimating the parameters of the study, which revealed that intellectual capital has positive impact on organizational performance in Pakistan. They concluded that establishment and development of human resources could be treated as intangible asset and reported as intellectual capital with long term value. On the Kenyan economic scene, related studies have been conducted, including the impact of International Financial Reporting Standards (IFRS) enforcement, as well as the relationship between human capital management practices and firm Performance in Kenyan commercial banks, amongst others (Outa, 2011). Regarding the management-focused investigation, the findings revealed that with the exception of communication, other human capital management practices have positive influence on firm performance as measured by turnover growth and return on assets. It was also evident that social capital is very important to firms as it facilitates exchange of information, higher access to resources, and exploitation of opportunities, coupled with contribution to greater firm performance.

Human resource empowerment equally brings about increased motivation and commitment to the organization, and encourages employees to work harder, thereby increasing overall firm performance. Three theories anchoring the dimensions of these studies include human capital theory, resource-based theory and productivity theory. The transaction cost and general system theories are also relevant to investigations of this nature. The transaction cost theory assumes that business enterprises choose governance structures that economize transaction costs associated with establishing, monitoring, evaluating, and enforcing mutual exchanges (Newman, 1999; Nelson, 2003; Oluka, 2019). The historical cost of human resources contextually represents the sacrifice made in getting employees. It seeks to recognize the actual cost incurred in recruiting selecting, hiring, training and development of employee, which are capitalized and amortized over the expected useful life of the human resource. If the asset is liquidated prematurely, losses are recorded and written off to profit and loss in the year, whereas if the asset has a longer life than estimated, revision is made in the amortization schedule. This treatment is similar to that given to physical fixed asset cost. It relates cost to revenue and provides basis for evaluation of return on investment, although it is unable to estimate the useful life of the assets.

Also anchoring on such theories, experts equally examined the effect of entrepreneur's human capital and 
social capital on the growth of Small Enterprises (SEs) in Sri Lanka. With data collected from 97 manufacturing enterprises that employ less than 50 employees in Colombo district of Sri Lanka, they sought to establish the relationship between human capital and firm growth, as well as the moderating effect of social capital on the relationship between human capital and firm growth. The findings revealed that human capital relates positively and directly to social capital. In addition, there was direct effect of human capital on firm growth, while social capital, in particular, moderated the relationship between human capital and firm growth (Newman, 1999; Oluka, 2019). Ekwe (2013) further used the VAIC model to compare both the intellectual capital indices and financial performance variables of six highly rated banks in Nigeria, in order to determine if deviations in their financial performance indices could be explained by the banks' intellectual capital variables. Using ex-post facto research design with longitudinal time series data spanning 2000-2012, the results revealed that banks with high intellectual capital recorded high financial performance.

\section{Conclusion and Recommendations}

Base on the statistical results, training cost has positive and significant effect on the return on equity and earnings per share of quoted manufacturing firms in Nigeria. This justifies the alternate hypotheses in favour of the concluding stance that human resource cost has significant effect on financial performance. It goes to substantiate the recognition that human capital expenditure fosters innovation and technological advancement leading to increased industrial productivity. Investment in human assets, especially in the area of training and development, thus, becomes more crucial to the success of firms in today's highly competitive economic environment. Ultimately, this study establishes that human resource cost has significant effect on the financial performance of quoted manufacturing firms in Nigeria. In view of this, it is recommended that quoted manufacturing firms should:

i. $\quad$ Further embrace the advocacy of championed by financial researchers/planners towards projecting human capital investment as a prime requisite for corporate performance, so as to enhance their human capital investment to total assets ratio; and

ii. Subscribe more visibly to the disposition that canvasses efficient classification and recognition of cost in terms of capital expenditure and revenue expenditure.

The above profile, which projects cost according to nature of expenditure, would go a long way in establishing accruing benefits from corporate spending on acquisition, recruitment, development, retention, training and retraining, which exceed the current accounting period. The counter-part profile would then distinguish the benefits appropriated within the accounting year from corporate spending on salaries, wages, commission, bonus, allowances and allied motivating incentives.

\section{References}

Abubakar, S. (2008). Human resource accounting: An assessment of the valuation models and methods. Nigerian Journal of Accounting Research, 4(2), 80-102.

Adebawojo, O. A., Enyi, P. E. \& Adebawo, O. O. (2015). Human asset accounting and corporate performance. American International Journal of Contemporary Research, 5(1), 45-52.

Beardwell, I. \& Holden, L. (2003). Human Resource Management: A Contemporary Approach.

Becker, G. (1962). Investments in human capital: a theoretical analysis. Journal of Political Economy, 70, 9-44.

Brummet, R. L., Flamholtz, E. G., \& Pyle, W. C. (1968). Human resource measurement: A challenge for accountants. The Accounting Review, 43(2), 217-224.

Canibano, L., García-Ayuso, M., Sánchez, M. P., \& Olea, M. (1999). Measuring Intangible to understand and improve Innovation Management-Preliminary results. Paper presented at the OECD International Symposium. The Accounting Review, 43(2), 217-224.

Cascio, W. F. (1998). The future world of work: Implications for human resources costing and accounting. Journal of Human Resource Casting \& Accounting, 3(2) 9-19.

Davies, S. D. (2018). Human resource accounting and shareholders wealth maximization: empirical study of Nigeria quoted manufacturing firms. International Journal of Business and Management Future, 2(1), 45-67.

Eatwell, J. M. \& Newman, P. (1991). The New Palgrave:A Dictionary of Economics. 3, 4 and 12.

Ekwe M. C. (2012). Relationship between Intellectual Capital and Financial Performance in the Nigerian Banking Sector (Unpublished PhD Accounting Dissertation), University of Nigeria, Nsukka.

Ekwe, M. C. (2013). The Relationship between human capital efficiency and financial performance: an empirical investigation of quoted Nigerian Banks. Research Journal of Finance and Accounting, 4(4), 148-154.

Flamholtz, E. G. (1971). A Model for Human Resource Valuation: A stochastic Process with Service Rewards. The Accounting Review, April, 253-267.

Flamholtz, E. G. (1999). Current issues, recent advancements, and future directions in human resource accounting. Journal of Human Resource Costing and Accounting, 4(1), 11-20.

Hermansson, R. H, (1964). Accounting for Human Assets. Occasional Paper No. 14, Michigan State University. Kharal, M., Zai-ur-Rehman, M.; Abrar, M. \& Khan, M. S. (2014). Intellectual Capital and Firm Performance: An 
Empirical Study on the Oil and Gas Sector of Pakistan. International Journal of Accounting and Financial Reporting, 4(1),56-67.

Lev, B. \& Schwartz, A. (1971). On the Use of the Economic Concept of Human Capital in Financial Statements. The Accounting Review, January, 103 - 112.

Micah, L. C., Ofurum, C. O., \& Ihendinihu, J. U. (2015).Firms financial performance and human resources accounting disclosure in Nigeria. International Journal of Business and Management, 7(14), 67-75.

Mirvis, P. H., \& Macy, B. A. (1976). Accounting for the costs and benefits of human resource development programmes: An interdisciplinary approach. Journal of Accounting, Organization and society, 1(2.3), 179193.

Nelson, M. (2003). Behavioural evidence on the effects of principles- and rules-based standards. Accounting Horizons, 17(1), 91-104.

Newman, B. H. (1999). Accounting Recognition of Human Capital Assets. New York: Pace University Press.

Okpala, P. O. \& Chidi O. C. (2010). Human capital accounting and its relevance to stock investment decisions in Nigeria. European Journal of Economics, Finance and Administrative Sciences, 4(2), 13-18.

Oloyo, R. A. (2001). Fundamentals of Research Methodology for Social and Applied Sciences.ROA Educational Press.

Oluka, N. O. (2019). Human Resource Cost and Financial Performance of Quoted Manufacturing Firms in Nigeria (Unpublished PhD Accounting Thesis), Ignatius Ajuru University of Education, Port Harcourt, Nigeria.

Osuala, E. C. (2001). Introduction to Research Methodology (3rd edition). Onitsha: Africana -FEP Limited.

Outa, R. O. (2011).The impact of financial reporting standards adoption on the accounting quality of listed companies in Kenya. International Journal of Accounting and Reporting. 1, 213-234.

Samuelson, P. A. \& Nordhaus, W. D. (1995) Economics (15th Edition). USA: McGraw-Hill.

Woodruff, R. L. \& Brummet, R. C. (1970). Discussion: R.G. Barry Human Resource Accounting, in The Behavioural Aspects of Accounting Data for Performance Evaluation, Edited by Burns, T.J. Columbus: Ohio State University.

Wright, P. M. \& McMahan, G. C. (1992). Human resources and sustained competitive advantages: A resourcebased perspective. International Journal of Human Resources Management, 5(2) 299-324. 